DOI: 10.4274/jarem.galenos.2020.3081

J Acad Res Med 2020;10(2):160-5

\title{
Investigation of Sexual Dysfunction in Premenopausal Women with Urinary Incontinence
}

\author{
(1) Ali Eroğlu1, (1) Muammer Aydın2, (10) Özkan Onuk1, (10) Nusret Can Çilesiz2, (1) Barış Nuhoğlu1 \\ ${ }^{1}$ Yeni Yüzyıl University, Gaziosmanpaşa Hospital, Clinic of Urology, İstanbul, Turkey \\ 2istanbul Gaziosmanpaşa Training and Research Hospital, Clinic of Urology, İstanbul, Turkey
}

Cite this article as: Eroğlu A, Aydın M, Onuk Ö, Çilesiz NC, Nuhoğlu B. Investigation of Sexual Dysfunction in Premenopausal Women with Urinary Incontinence. J Acad Res Med 2020;10(2):160-5

\begin{abstract}
Objective: In this study, "Female Sexual Dysfunction (FSD)" was investigated in women who applied to our urology outpatient clinics who suffered from urinary incontinence $(\mathrm{UI})$ and healthy women who did not have $\mathrm{UI}$ to evaluate the effect of $\mathrm{UI}$ and incontinence types on Female Sexual Functions (FSF).

Methods: A total of 220 female patients who applied to urology and incontinence outpatient clinics between October-December 2016 were included in the study. Of these 220 female cases, 110 of them were patients without complaints of UI. In patients with complaints of UI, type of UI has been identified "female sexual function Index (FSFI)" test was used to determine FSF status in all cases.

Results: The rate of KCD was found to be $60 \%(n=66)$ in the UI group and $36.4 \%(n=40)$ in the control group. The rate of FSD was significantly higher in the UI group ( $\mathrm{p} \square$ 0.05). When the FSFI scores were evaluated, FSFI desire, arousal, lubrication, orgasm, satisfaction scores were significantly lower in the UI group than those in the control group ( $\mathrm{p} \square 0.05)$. When urge, stress, mixed incontinence groups were evaluated, there were no significant differences between FSFI scores and sexual dysfunction status ( $p \square 0.05$ ).

Conclusion: In our study, we found that $\mathrm{UI}$ is one of the factors that increase incidence of sexual dysfunction. Therefore, we think that the cases with UI complaints should be evaluated in terms of FSD. In addition, when we looked at UI types separately to evaluate the effects of UI on sexual dysfunction, we found that there was no significant difference between them in terms of influencing sexuality.
\end{abstract}

Keywords: Urinary incontinence, female sexual dysfunction, premenopausal, urogynecology

\section{INTRODUCTION}

Urinary incontinence (UI) is a social and hygienic disease that can occur at any age, is common and affects life negatively. UI is a complex problem that occurs for different reasons. It is not just a medical problem. It also affects the quality of life, which is defined as physical, psychological, economic and social well- being. Although the frequency of $\mathrm{UI}$ increases with age, it can be seen not only in the elderly population but also in the young and middle-aged population (1).

Female sexual dysfunction (FSD) is a common disease and its incidence varies between 19 and 50\% in the literature (2). UI can impair women's sexual health to various degrees. Causes

ORCID IDs of the authors: A.E. 0000-0002-5545-5892; M.A. 0000-0002-4328-7262; Ö.O. 0000-0001-6497-0418; N.C.Ç. 0000- 0003-2115-698X; B.N. 0000-0002-8737-4050. 
such as psychological pressure, fear of UI during sexual intercourse and worry of bad smell play a role in the etiology (3). It is reported that UI causes FSD and the frequency of sexual dysfunction varies between $26 \%$ and $43 \%$ in the female group with incontinence (4).

Studies investigating the effect of UI types (stress-urge-mixt) on female sexual functions are available in the literature. In some studies, it has been found that incontinence types do not make any difference in affecting sexuality (5). In another study evaluating the effect of UI on sexual functions in our country, it was shown that the effect of mixed UI on sexual functions was higher than other groups (6).

Sexual functions are an important part of quality of life. The selfconfidence of women who miss urine significantly decreases, becoming ashamed, avoiding the relationship and ultimately this situation negatively affects the sexual pleasure of the woman (7). It is important that they are questioned in terms of sexual function in the evaluation of $\mathrm{UI}$ cases in the light of this information.

In this study, we investigated the rates of female sexual dysfunciton in healthy women with similar demographic characteristics, UI complaints and aimed to evaluate the effect of UI on female sexual function.

\section{METHODS}

A total of 220 female patients who were admitted to the urology and incontinence polyclinics between October 2016 and December 2016 were included in our study. Of these 220 female cases, 110 have complaints of $\mathrm{UI}$; the other 110 were randomized cases without UI.

The subjects included in the study were sexually active and married women, all of whom were in the premenosal period. Patients who were pregnant or breastfeeding, patients with a history of gynecological operations, and patients with a history of malignancy were not included in the study.

Patients filled out questionnaire forms themselves, in a relaxed and quiet environment. The age, education status, occupation, monthly income, age of marriage, duration of marriage, status and number of children, whether they have a chronic disease, history of surgery were questioned and recorded.

The type of UI in patients with UI was determined by taking into account the standardization determined by the International incontinence Association and accompanied by questionnaire forms. They were questioned about how long they had been urinating. The International Consultation on Incontinence Questionnaire-Short Form (ICIQ-SF) questionnaire was filled out to determine the effects of UI on quality of life.

In all cases, the "Female Sexual Function Index" (FSFI) test, developed by Rosen et al. as a multidimensional scale in 2000, was used to determine female sexual function status. FSFI is a test that we use frequently, with Turkish validity and reliability studies consisting of 6 sections (sexual desire, arousal, lubrication, orgasm, satisfaction, pain) and 19 questions, evaluating sexual function and problems in the last 4 weeks. The scores obtained in the subheadings were multiplied by their own coefficient, resulting in the subheadings and total points, with a total score of 2 to 36 . In our study, the threshold for FSFI was considered to be 23 . The study was approved by the Clinical Research Ethics Committee of the Gaziosmanpaşa Training and Research Hospital.

\section{Statistical Analysis}

Mean, standard deviation, median lowest, highest, frequency and ratio values were used in the descriptive statistics of the data. The distribution of variables was measured by Kolmogorov- Simirnov test. Kruskal-Wallis, Mann-Whitney $\mathrm{U}$ test were used in the analysis of quantitative independent data. Chi-square test was used in the analysis of qualitative independent data. SPSS program was used for analysis. The reference $p$ value was $<0.05$.

\section{RESULTS}

The patients were randomized into two groups: group 1 (case group-UI), group 2 (control group). There were no statistically significant differences between these two groups in terms of socio-demographic data, presence of chronic disease, drug use, history of previous surgery $(p>0.05$ ) (Table 1 ).

In group 1 ( $n=110)$, urgency was present in $28(25.5 \%)$ of cases, stress in $24(21.8 \%)$ and mixt UI in 58 (52.7\%). Of these patients, $56(50.9 \%)$ did not receive any treatment, while 54 (49.1\%) had a history of treatment.

When we evaluated all the FSFI scores, all scores in group 1 except pain score were significantly lower than those in group 2 $(p=0.05)$. When FSFI total scores were evaluated, the rate of sexual dysfunction in group 1 was significantly higher than in group 2 (60\%-36.4\%) ( $p=0.05)$ (Table 2).

In group 1, there was no statistically significant difference between the two groups in comparison to the individual sociodemographic data of the patients with UI types (urge-stress-mixt incontinence). The mean age of the cases was 36, 41.3 and 40.1 years, respectively.

In this study, ICIQ-SF questionnaire was completed to determine the effects of $\mathrm{UI}$ on quality of life in patients with incontinence. Accordingly, the ICIQ-SF score did not differ significantly in urge, stress, mixt incontinence groups.

FSFI scores and sexual dysfunction rates in urge, stress, mixt incontinence groups were not significantly different $(p>0.05)$. There were 66 cases of sexual dysfunction and UI, 16 cases of urgency, 14 cases of stress and 36 cases of mixt type incontinence. There was no significant difference in the incidence of sexual dysfunction among all three groups ( $p>0.05$ ) (Table 3 ).

\section{DISCUSSION}

Sexual function in humans consists of a series of reactions involving complex interactions of psychological, physiological 
and behavioral components (8). FSD is a common disease and its incidence in the literature varies between 19-50\% (2). A national study conducted in Canada found sexual dysfunction in $39 \%$ of the 18-44 age group (9). Age is an important factor in some of the factors that affect women's sexual health. In our study, the rate of sexual dysfunction was significantly increased with older age. Similarly, Cayan et al. (10) and Lukacz et al. (11) also determined that female sexuality is negatively affected with increasing age. However, Lauman et al. (12) stated that the rate of FSD was higher in young women.

In our study, we found that the rate of FSD decreases as the level of education increases. In line with our findings, there are studies that have found that low education level increases the risk of sexual dysfunction $(13,14)$. Some studies in the literature also questioned the educational status of the woman's partner (15). In our study, it is a handicap to not know the educational status of the woman's partner. It may be thought that the high level of education of the woman or her partner may be a helpful factor in the issues such as sharing the current problem between couples and applying for the necessary professional help.

In our study, we found that the increase in duration of marriage and the low age of first marriage increased the likelihood of sexual dysfunction. Singh et al. (16) similarly found that the longer the duration of marriage, the greater the frequency of FSD. These findings can be explained by the increase of factors that lead to the risk of developing FSD, such as the progression of age and the presence of chronic disease as the duration of marriage increases.

Although the pathophysiology of UI has not been fully clarified, its negative effect on sexual function is known. Psychological pressure, fear of UI during sexual intercourse and anxiety of bad smell play a role in the etiology (3). The first study on the relationship between UI and FSD was conducted by Scott and Hsueh (17) and published in 1979. There are studies (4) reporting that the frequency of FSD varies between $26 \%$ and $43 \%$ in patients with UI. Shaw (18) also reported that $46 \%$ of patients with $\mathrm{UI}$ and lower urinary system complaints were

\section{Table 1. Socio-demographic data of the cases}

\begin{tabular}{|c|c|c|c|c|c|}
\hline & \multicolumn{2}{|c|}{ Group 1 (case group) } & \multicolumn{2}{|c|}{ Group 2 (control group) } & \multirow{2}{*}{$\mathrm{p}$} \\
\hline & Mean $\pm S D(n, \%)$ & Med & Mean \pm SD $(n, \%)$ & Med & \\
\hline Age (year) & $39.3 \pm 8.7$ & 43.0 & $36.6 \pm 9.4$ & 38.0 & $0.052^{m}$ \\
\hline BMI $\left(\mathrm{kg} / \mathrm{m}^{2}\right)$ & $29.5 \pm 5.3$ & 28.4 & $28.8 \pm 4.3$ & 28.1 & $0.466^{m}$ \\
\hline \multicolumn{6}{|l|}{ Educational status } \\
\hline Primary school & $16(14.5 \%)$ & - & $6(5.5 \%)$ & \multirow{5}{*}{$0.134^{x^{2}}$} & \\
\hline Secondary school & 52 (47.3\%) & - & 50 (45.5\%) & & \\
\hline High school & $10(9.1 \%)$ & - & $28(25.5 \%)$ & & \\
\hline University & $24(21.8 \%)$ & - & $18(16.4 \%)$ & & \\
\hline Post graduate & $8(7.3 \%)$ & - & $8(7.3 \%)$ & & \\
\hline \multicolumn{6}{|l|}{ Occupation } \\
\hline Housewife & 82 (74.5\%) & - & 69 (62.7\%) & \multirow{3}{*}{$0.058^{x^{2}}$} & \\
\hline Worker & $12(10.9 \%)$ & - & $23(20.9 \%)$ & & \\
\hline Memur & $16(14.5 \%)$ & - & $16(14.5 \%)$ & & \\
\hline \multicolumn{6}{|l|}{ Monthly income } \\
\hline None & $84(76.4 \%)$ & - & $67(60.9 \%)$ & \multirow{4}{*}{$0.063^{x^{2}}$} & \\
\hline$<1500 \mathrm{TL}$ & $12(10.9 \%)$ & - & $25(22.7 \%)$ & & \\
\hline $1500-3000$ & $8(7.3 \%)$ & - & 12 (10.9\%) & & \\
\hline$>3000 \mathrm{TL}$ & $6(5.5 \%)$ & - & $6(5.5 \%)$ & & \\
\hline \multicolumn{6}{|l|}{ Dating } \\
\hline Arranged & $70(63.6 \%)$ & - & 78 (70.9\%) & \multirow{2}{*}{$0.250^{x^{2}}$} & \\
\hline Friendship & $40(36.4 \%)$ & - & $32(29.1 \%)$ & & \\
\hline Number of children & $2.5 \pm 1.3$ & 3.0 & $2.4 \pm 1.4$ & 2.0 & $0.398^{m}$ \\
\hline
\end{tabular}


Table 2. Comparison of Female Sexual Function Index score data of cases

\begin{tabular}{|c|c|c|c|c|c|c|}
\hline & & \multicolumn{2}{|c|}{ Group 1 (case group) } & \multicolumn{2}{|c|}{ Group 2 (control group) } & \multirow{2}{*}{$p$} \\
\hline & & Mean \pm SD & Med & Mean \pm SD & Med & \\
\hline \multicolumn{7}{|l|}{ FSFI } \\
\hline \multicolumn{2}{|l|}{ Desire } & $3.2 \pm 1.1$ & 3.6 & $4.1 \pm 1.0$ & 4.2 & $0,000^{m}$ \\
\hline \multicolumn{2}{|l|}{ Arousal } & $3.3 \pm 1.1$ & 3.3 & $4.0 \pm 1.0$ & 3.6 & $0,000^{m}$ \\
\hline \multicolumn{2}{|l|}{ Lubrication } & $4.0 \pm .8$ & 3.9 & $4.3 \pm .7$ & 4.5 & $0,005^{m}$ \\
\hline \multicolumn{2}{|l|}{ Orgasm } & $3.4 \pm 1.3$ & 3.6 & $4.3 \pm 1.0$ & 4.0 & $0,000^{m}$ \\
\hline \multicolumn{2}{|l|}{ Satisfaction } & $3.6 \pm 1.3$ & 3.6 & $4.2 \pm 1.1$ & 4.0 & $0,000^{m}$ \\
\hline \multicolumn{2}{|l|}{ Pain } & $4.0 \pm 1.4$ & 4.0 & $4.0 \pm 1.0$ & 4.0 & $0,555^{\mathrm{m}}$ \\
\hline \multicolumn{2}{|l|}{ Total } & $21.4 \pm 5.1$ & 22.0 & $24.9 \pm 4.7$ & 24.3 & $0,000^{m}$ \\
\hline \multirow{2}{*}{ Sexual dysfunction } & $(+)$ & 66 & $\% 60$ & 40 & $\% 36.4$ & \multirow{2}{*}{$0,003^{x}$} \\
\hline & $(-)$ & 44 & $\% 40$ & 70 & $\% 63.6$ & \\
\hline
\end{tabular}

Table 3. Comparison of Female Sexual Function Index score data in urinary incontinence cases

\begin{tabular}{|c|c|c|c|c|c|c|c|c|}
\hline & & \multicolumn{2}{|c|}{ Urge Incontinence } & \multicolumn{2}{|c|}{ Stress Incontinence } & \multicolumn{2}{|c|}{ Mixt Incontinence } & \multirow{2}{*}{$p$} \\
\hline & & Mean \pm SD & Med & Mean \pm SD & Med & Mean \pm SD & Med & \\
\hline \multicolumn{9}{|l|}{ FSFI } \\
\hline \multicolumn{2}{|l|}{ Desire } & $3.5 \pm 1.1$ & 3.6 & $3.3 \pm 1.3$ & 3.3 & $3.1 \pm 1.1$ & 3.6 & $0,246^{K}$ \\
\hline \multicolumn{2}{|l|}{ Arousal } & $3.3 \pm 1.0$ & 3.3 & $3.2 \pm 1.3$ & 3.0 & $3.3 \pm 1.1$ & 3.3 & $0,785^{K}$ \\
\hline \multicolumn{2}{|l|}{ Lubrication } & $4.0 \pm 0.7$ & 3.9 & $3.8 \pm 0.8$ & 3.9 & $4.1 \pm 0.8$ & 4.2 & $0,105^{K}$ \\
\hline \multicolumn{2}{|l|}{ Orgasm } & $3.2 \pm 1.2$ & 3.4 & $3.7 \pm 1.5$ & 3.8 & $3.3 \pm 1.3$ & 3.6 & $0,367^{K}$ \\
\hline \multicolumn{2}{|l|}{ Satisfaction } & $3.8 \pm 1.0$ & 3.8 & $3.5 \pm 1.5$ & 3.2 & $3.6 \pm 1.3$ & 3.6 & $0,501^{K}$ \\
\hline \multicolumn{2}{|l|}{ Pain } & $3.9 \pm 1.1$ & 3.8 & $3.6 \pm 1.6$ & 3.6 & $4.1 \pm 1.4$ & 4.4 & $0,205^{K}$ \\
\hline \multicolumn{2}{|l|}{ Total } & $21.7 \pm 4.6$ & 22.0 & $21.0 \pm 5.8$ & 19.7 & $21.5 \pm 5.1$ & 22.8 & $0,830^{\mathrm{K}}$ \\
\hline \multirow{2}{*}{ Sexual dysfunction } & $(+)$ & 16 & $\% 57$ & 14 & $\% 58.3$ & 36 & $\% 62.1$ & \multirow{2}{*}{$0,962^{x}$} \\
\hline & $(-)$ & 12 & $\% 43$ & 10 & \%41.7 & 22 & \%37.9 & \\
\hline
\end{tabular}

found to have sexual dysfunction. In a study conducted by Turhan (13) in Turkey, FSFI threshold value was taken as 22.7 and sexual dysfunction was detected in $48.3 \%$ of all cases, $34 \%$ of cases in the reproductive period and $54 \%$ of cases with $\mathrm{UI}$ in the reproductive period. In our study, we considered FSFI threshold as 23 and found the rate of sexual dysfunction as $48.18 \%$ in all cases $(n=220)$. This ratio was found to be $60 \%$ in the patients with UI (group 1) and $36.4 \%$ in the control group (group 2). When we looked at FSFI total scores, the rate of sexual dysfunction in the UI group was significantly higher than in the control group (60\%-36.4\%). The results we found were parallel to those in similar studies (6-8).

In our study, when we evaluated FSFI scores according to UI types, we could not find a significant difference in terms of
FSFI scores. Similarly, Turhan (13) and Urwitz-Lane and Özel (5) also found that there was no statistically significant difference between the UI types in terms of FSFI scores in reproductive incontinence cases. When we look at the literature, we see different results. Güdücü and Keser Özcan (19) states that the sexual function of women with mixt incontinence is worse than that of women with stress and urge type incontinence. In another study conducted in Iran, mixt UI was found to affect sexual function more than stress and urge type incontinence (20). Gordon et al. (21) stated that the sexual function scores of mixt incontinence patients were higher than those of stress incontinence patients.

Sexual functions are an important part of quality of life. The self-esteem of women who miss urine decreases are 
embarrassed and they escape from the relationship. As a result, this situation prevents them from enjoying sexuality. In addition, the relationship of the couple and the marriage institution can be negatively affected. Yip et al. (22) found that emotional problems related to sexual satisfaction and $\mathrm{UI}$ in patients with stress incontinence, and decreased sexual satisfaction in patients with overactive bladder negatively affect the marriage.

It should be kept in mind that incontinence treatment can have a positive effect on sexual function and overall quality of life. Arslan et al. (23) found significant increase in FSFI scores in follow-up after transobturator tape (TOT) operation due to stress UI (SUI). In a recent metaanalysis evaluating sexual function after SUI surgery, $55.5 \%$ of all SUI surgeries [TOT, transvaginal tape (TVT)], Burch colposusception, autologous facial sling) reported no changes in sexual symptoms, 31.9\% improvement and $13.1 \%$ worsening. Sexual symptoms for miduretral sling operations were reported to be $56.7 \%$ unchanged, $33.9 \%$ improved, and $9.4 \%$ worsened. When the improvement rates in symptoms were compared, no significant difference was found between both midurethral sling operations (TOT and TVT) (24). As stated by Ayyıldız et al. (25), information should be given that patients who are planning to have a vaginal intervention due to UI may experience some sexual function parameters such as dyspareunia, even if a general sexual dysfunction does not develop. This information also shows that the treatment that will be performed will provide significant improvement in sexual function and therefore in the quality of life of the partners.

\section{Study Limitations}

The fact that our study was single-centered and that couples were not evaluated in terms of sexual function can be seen as a limitation. In addition, UI cases could be treated and reevaluated in terms of sexual function, and may provide additional contribution to the study.

\section{CONCLUSION}

Considering the incidence of continent cutaneous diversion and $\mathrm{UI}$ together, sexual function must be questioned in patients with UI. In addition to similar studies in the literature, we would like to identify this situation and emphasize that the treatment should be planned. It should be kept in mind that incontinence can negatively affect sexual functions when patients are left without treatment, and this can decrease quality of life and get a vicious circle.

Ethics Committee Approval: The study was approved by the Clinical Research Ethics Committee of the Gaziosmanpaşa Training and Research hospital.

Informed Consent: It was obtained.

Peer-review: Externally peer-reviewed

Author Contributions: Concept - A.E., M.A., Ö.O., N.C.Ç., B.N.; Design - A.E., M.A., Ö.O., N.C.Ç., B.N.; Supervision - A.E., M.A., Ö.O., N.C.Ç.,
B.N.; Resources - A.E.; Data Collection and/or Processing - A.E., N.C.Ç.; Analysis and/ or Interpretation - A.E., M.A., Ö.O., N.C.Ç.; Literature Search - A.E., M.A.; Writing Manuscript - A.E., M.A.; Critical Review - A.E., M.A., Ö.O., N.C.Ç., B.N.

Conflict of Interest: The authors have no conflict of interest to declare.

Financial Disclosure: The authors declared that this study has received no financial support.

\section{REFERENCES}

1. Hsieh CH, Lee MS, Lee MC, Kuo TC, Hsu CS, Chang ST. Risk factors for urinary incontinence in Taiwanese women aged 20-59 years. Taiwan Obstet Gynecol 2008; 47:197-202.

2. Dalpiaz $O$, Kerschbaumer A, Mitterberger M, Pinggera GM, Colleselli D, Bartsch G, et al. Female sexual dysfunction: a new urogynaecological research field. BJU Int 2008; 101: 717-21.

3. Aslan G, Köseoğlu H, Sadik O, Gimen S, Cihan A, Esen A. Sexual function in women with urinary incontinence. Int J Impot Res 2005; 17:248-51.

4. Barber MD, Dowsett SA, Mullen KJ, Viktrup L. The impact of stress urinary incontinence on sexual activity in women. Cleve Clin J Med 2005; 72: 225-32

5. Urwitz-Lane R, Özel B. Sexual function in women with urodynamic stress incontinence, detrusor overactivity, and mixed urinary incontinence. Am J Obstet Gynecol 2006; 195: 1758-61.

6. Coksuer H, Ercan CM, Haliloğlu B, Yucel M, Cam C, Kabaca C, et al. Does urinary incontinence subtypes affect sexual function? Eur J Obstet Gynecol Reprod Biol 2011; 159: 213-7.

7. Akhan SE. Pelvis tabanı ve Cinsel Yaşam: Bölüm 51. Yalçın Ö, ed. Temel Ürojinekoloji. 1. Baskı. İstanbul, Nobel Tıp Kitabevleri Ltd. şti. 2009: 52541.

8. Riley A, Riley E. Releavant Issues in the Diagnosis and Management of Psychosexual Disorders. Primary Care Psychiatry 1999; 5:161-5.

9. Fisher WA, Boroditsky R, Bridges ML. The 1998 Canadian contraception study. Can J Hum Sexuality 1999; 8:161-216.

10. Cayan S, Akbay E, Bozlu M, Canpolat B, Acar D, Ulusoy E. The prevelance of female sexual dysfunction and potential risk factors that may impair sexual function in Turkish women. Urol Int 2004; 72: 52-7.

11. Lukacz ES, Whitcomb EL, Lawrence JM, Nager CW, Contreras R, Luber KM. Are sexual activity and satisfaction affected by pelvic floor disorders? Analaysis of a community-based survey. Am J Obstet Gynecol 2007; 197: 1-6.

12. Laumann EO, Paik A, Rosen RC. Sexual dysfunction in the United States: prevalence and predictors. JAMA 1999; 281: 537-44.

13. Turhan A. Üriner inkontinansın reprodüktif ve postmenopozal dönemde kadın cinsel fonksiyon bozuklukları üzerine etkisi. İstanbul Üniversitesi İstanbul Tıp Fakültesi Kadın Hastalıkları ve Doğum Anabilim Dalı Tıpta Uzmanlık Tezi. 2010.

14. Goldmeier D, Judd A, Schroeder K. Prevalence of sexual dysfunction in new heterosexual attenders at a central London genitourinary medicine clinic in 1998. Sex Transm Infect 2000; 76: 208-9.

15. Kömürcü N, İşbilen $A$. Postmenopozal dönemde kadınların cinsel yaşama uyumu. Turk J Urol 2011; 37: 326-30.

16. Singh JC, Tharyan P, Kekre NS, Singh G, Gopalakrishnan G. Prevalence and risk factors for female sexual dysfunction in women attending a medical clinic in south India. J Postgrad Med 2009; 55: 113-20.

17. Scott RS, Hsueh GS. A clinical study of the effects of galvanic vaginal muscle stimulation in urinary stress incontinence and Sexual dysfunction. Am J Obstet Grnecol 1979; 135: 663-5.

18. Shaw C. A systematic review of the literature on the prevelance of the sexual impairment in women with urinary incontinence and the prevelance of urinary leakage during sexual activity. Eur Urol 2002; 42:432-40.

19. Güdücü N, Keser Özcan N. Üriner İnkontinanslı Kadınların Cinsel Fonksiyonlarının Değerlendirilmesi. JAREN 2016; 2: 16-23.

20. Zohre M, Minoo P, Ali M, Azam B. Sexual function in woman with urinary incontinence: a cross-sectional study from Iran. Scientific Academic Publishing 2013; 2: 31-5.

21. Gordon D, Groutz A, Sinai T, Wiezman A, Lessing JB, David MP, et al. Sexual function in women attending a urogynecology clinic. Int Urogynecol J Pelvic Floor Dysfunct 1999; 10: 325-8. 
22. Yip SK, Chan A, Pang S, Leung P, Tang C, Shek D, et al. The impact of urodynamic stress incontinence and detrusor overactivity on marital relationship and sexual function. Am J Obstet Gynecol. 2003; 188: 12448.

23. Arslan B, Onuk O, Eroglu A, Gezmis TC, Aydin M. Female sexual function following a novel transobturator sling procedure without paraurethral dissection (modified-TOT). Int Braz J Urol 2017; 43: 142-9.
24. Jha S, Ammenbal M, Metwally M. Impact of incontinence surgery on sexual function: a systematic review and meta-analysis. J Sex Med 2012; 9: 34-43.

25. Ayyıldız A, Akgül T, Germiyanoğlu C. Stres üriner inkontinans tedavisi için yapılan vajinal girişimler sonrası kadınlarda cinsel fonksiyon. Androloji Bülteni, 2006; 241: 82-5. 